\title{
Study on the Construction Dilemma and Improvement Path of Private High - level Universities in Shaanxi Province
}

\author{
Keyin Liang \\ Xi' an International University, Xi' an, Shaanxi, 710077
}

Keywords: Shaanxi Province, Private High-level University, Construction Dilemma

\begin{abstract}
At present, with the further deepening of reform and opening up, how to promote the comprehensive progress of society, how to deepen the educational reform has become a major theoretical and practical problem of school education. With the deepening of the development and reform of colleges and universities in our country, private colleges and universities have gradually developed into an important part of our universities. In recent years, private education has flourished in various parts of the country. As an important content of college education, how to carry out the work is one of the important criteria to measure the overall work of colleges and universities. It is also the fundamental requirement of social development to cultivate talents. Due to the conditions, scale, system and guiding ideology of the running of private colleges and universities, the efficiency of running schools is also very different. We must strengthen the management of private colleges and universities.
\end{abstract}

\section{Introduction}

Shaanxi Province is located in the western part of China, ranking the middle reaches of the Yellow River, is located in the hinterland of China's interior, north and Inner Mongolia, Ningxia border, west and Gansu connected, south and Sichuan, Chongqing, Hubei Tong, east and Shanxi, Henan adjacent to China's northwest Portal, is to connect China's eastern and central regions and northwest, southwest of the transport hub. The province is more than 1,000 kilometers long from north to south, east-west width of $360 \mathrm{~km}$, showing the north and south high and long, low in the middle, narrow terrain, is a typical landform provinces in China. The northern part of the northern Shaanxi plateau (hilly gully), the central Guanzhong Plain (flat), the southern Qinba mountain (basin gorge phase). On the natural conditions, southern Shaanxi, northern Shaanxi, the natural conditions are poor. Shaanxi Province has an important strategic position, the provincial capital of Xi'an is one of the four ancient cultural capital, has a long cultural heritage. At the turn of the century, the CPC Central Committee has made a strategic decision on the development of the western region and has had a positive impact on the overall development of the social, political, economic and cultural aspects of the western region. Shaanxi Province, as the political, economic, scientific and cultural center of the northwest region, is at the forefront of the western development and plays a demonstration and leading role in the development of the northwest region. Shaanxi is China's education province, but also China's western region science and technology education base. In this important historical period, Shaanxi private education is booming. By the end of 2003, the Ministry of Education announced 12 private colleges and universities in Shaanxi Province. Shaanxi private college has enrollment 61000 people, the size of students in the school to reach 14 million people, about $49 \%$ of the total number of public college students in Shaanxi Province, accounting for $14.2 \%$ of the number of private college students in the country. According to statistics, in the country more than 11 million people in the scale of private colleges and universities, Shaanxi occupy five, of which Xi'an Translation Training Institute with its 30,000 people in the scale, ranking first in the country. Shaanxi Province is the formation of private colleges and universities in the scale of running schools and the average trend of public institutions.

\section{Major Problems and Dilemmas Facing the Construction of High - level Universities}

School orientation is a fundamental direction of the development of a university, is a university 
development strategy of the basic choice, but also a university top design core and foundation. In general, it includes the target positioning, type positioning, hierarchical positioning, scale positioning, subject positioning, feature positioning and so on. In recent years, with the development of China's higher education and the deepening of the reform of higher education system, university stratification, classification and diversification, the trend of the development of more and more obvious, in this context, colleges and universities are able to identify Their own position, to determine a reasonable school orientation, on their own development is of great significance. But an overview of China's local high-level university's school orientation, you can find a lot of colleges and universities in the choice of the objectives of the school there are some errors. This is mainly reflected in: the goal of running a school is not clear, not clear, not in-depth study of national and local higher education system characteristics, trends and requirements, but also the lack of accurate understanding of the local economic and social development, while their own school conditions, school Level, school quality, school efficiency and other aspects of the lack of a more clear understanding. Although most colleges and universities have proposed to build the school into a regional characteristics of the domestic first-class high-level university's goal, "However, how to reflect their respective regional characteristics, and then solve the characteristics of discipline selection and cultivation, local personnel training, stability Optimize the teaching staff to enhance the level of cooperation with industry and education, combined with regional industrial structure to promote local economic, technological and social development and other issues, it seems that no accurate positioning has been found. In the school type and level, there is a blind comparisons phenomenon, not according to the local social needs and their own conditions, blindly pursue the "comprehensive", "research", "international", leading to school model convergence, the formation of the school side Situation, lack of personality and characteristics. In the school scale and discipline development, blind "greed" big, "seeking" the whole, resulting in shortage of teachers, school premises, lack of equipment, lack of books, leading to the decline in the quality of education. Scientific and rational orientation is the prerequisite for colleges and universities to seek development improves quality and make features. At present, the problems of local high-level universities are in running the school not only seriously affect their own healthy and sustainable development, but also is not conducive to the construction of diversified, multi-level, multi-type and open higher education system and higher education as a whole Level of improvement.

Discipline is the basic unit of the existence of university organization system, the level of academic development is a university at home and abroad status of the main signs, there is no first-class disciplines, never built as first-class university. Because of this, in recent years, local high-level universities in the process of creating a domestic first-class university are very important to discipline construction work, have taken such as to increase the intensity of discipline construction efforts, and actively introduce academic leaders, strengthen the discipline team construction and so on Measures, so that the level of their own discipline construction has been significantly more than before. But in the affirmative results at the same time, we should also see the current local high-level university in the discipline construction there are still areas to be strengthened and improved.

The history of the evolution of modern university functions shows that the social service function is the objective requirement of the modern society development to the university, and also the embodiment of the university vitality and the existence value. From the reality of local colleges and universities in China, local colleges and universities should also be based on local economic development and social progress services, relying on local resources to seek their own sustainable development. In recent years, the local high-level university's understanding of the social service function has been improved, many schools to serve the local economic and social development as the school's philosophy, the social service work into the overall planning, combined with local economic and social development The actual needs of a number of effective social services work. But subject to various reasons, the current high level of local universities in the social service mechanism and service functions play, there are still some of the more prominent issues. 


\section{Suggestions on Developing School Physical Education in Non-governmental Institutions of Higher Learning in Shaanxi Province}

The development of the western region provides a rare historical opportunity for the development of private colleges and universities in Shaanxi Province. It also provides an opportunity for the development of school sports in private colleges. Private colleges and universities should cultivate the quality of students and cultivate the professional talents of moral, intellectual and physical development, Make full use of the policy support and learn from advanced school experience, for the comprehensive development of school sports, and comprehensively enhance the quality of personnel on the needs of physical education. Firmly grasp the superior environment of many colleges and universities in Shaanxi Province, for the development of private colleges and universities to bring rich experience and create a good atmosphere. Strengthen the management concept of private colleges and universities in Shaanxi Province, improve the management system, changes the understanding of physical education, the formation of a virtuous circle of quality education

Private colleges and universities in Shaanxi Province should speed up the pace of expansion of physical education teachers, and actively introduce sports professionals to make up for the lack of the status of physical education teachers. We should speed up the establishment of personnel system, so that private college physical education teachers and public colleges and universities have the same social status, change the lack of private college physical education teachers. Change the use mechanism of the PE teachers in private colleges and universities in Shaanxi province, and improve the social security and basic welfare of teachers. Reduce the workload of PE teachers in private colleges and universities, and create a good academic atmosphere. The establishment of the private colleges and universities in Shaanxi Province, the training of teachers, training, the corresponding rules and regulations, the introduction of incentives for outstanding teachers.

Shaanxi Province, private colleges and universities should strive to open more types and projects of physical education, and more to open sports elective courses to improve the teaching method to change the private college physical education content of a single, teaching organization form of rigid situation, to enhance the interest in student sports and excitation. To stimulate students 'enthusiasm for physical education, to meet the students' choice of sports, the development of their sports interest. Should be standardized and perfect the implementation of physical education teaching documents, increase the supervision and inspection of school physical education, rectify the school physical education teaching order, correct understanding of physical education, should pay attention to teaching effectiveness, and strive to improve the teaching effect, strict student physical education Of the discipline requirements, to ensure the normal conduct of private college physical education. Reform the practice of physical education in private colleges and universities, promote the effect of physical education, strengthen the evaluation of physical education in private colleges and universities, improve the quality of physical education in private colleges and universities in Shaanxi Province, and ensure the physical and mental health of students.

In order to improve the quality of PE teaching, private colleges and universities should actively carry out extracurricular activities in sports, and should actively study the relevant system and measures for formulating extracurricular sports activities and improve them in sports facilities, so as to create good external conditions for students to attract more students participate in extracurricular sports activities. Earnestly do extracurricular sports activities exercise and competition, the formation of a complete system of school sports, better completion of the purpose of school sports tasks, and truly achieve a comprehensive quality education. Shaanxi Province private colleges and universities should be through extracurricular sports activities to consolidate and improve the students learned the knowledge and skills in the classroom, fully embodies the main role of students, give full play to the enthusiasm of student sports activities, training private college students' sports interest and ability to establish the right Sports value orientation. Through physical education and extracurricular sports activities, so that students master the method of scientific physical exercise, training students awareness of the importance of physical exercise, lifelong sports to lay a good foundation, and truly private college physical education in the national fitness play a role in the 
future The We will be able to create an extracurricular sports club, and strive to create a favorable environment for students to carry out extracurricular sports activities, and to develop school sports. It is necessary to create an extracurricular sports club which is popular with college students and special colleges and universities. Space, and truly make private college physical education for the cause of the national fitness to lay a good foundation.

\section{Conclusion}

Shaanxi province private college has physical education teachers from the external retirees to the initial formation of a fixed and part-time coexistence, self-contained system of a faculty. This structure of the faculty is the characteristics of private colleges and universities in Shaanxi Province. But the number of teachers is insufficient, the workload is large, the lack of training mechanism is the main problem of teachers. Speed up the reform of the school sports system in private colleges and universities in Shaanxi Province, make use of the flexible running mechanism of private colleges and universities, learn from the experience of advanced schools at home and abroad, create a new private school sports model, create a good fitness environment, do the characteristics, do the level.

\section{Acknowledgements}

Shaanxi Social Science Fund Project "high level of private university construction theory and practice research" (No.: 12N109)

Shaanxi Department of Education research project "China's private higher education research new progress" (No.: 13JZ076)

Shaanxi Department of Education research project "Shaanxi high level private university construction and connotation development strategy research" research results (No.: 13JZ075)

\section{References}

[1] Gao Weiyun. Quality Features Innovation: the guarantee of sustainable development of private colleges and universities [J]. Journal of Lanzhou University, 2004 (02)

[2] Chen Yong, Du Xi Min. The development of private colleges and universities in Shaanxi [J]. Journal of Shaanxi Normal University Journal of Continuing Education, 2003 (S1)

[3] Lei Junli, Li Yangli, Wang Jinggui. Micro-thinking on the reform of physical education in private colleges and universities [J]. Journal of Shaanxi Normal University, 2003 (S1)

[4] Qu Hongbo, Lin Hefeng. Investigation and Analysis on the Present Situation of Physical Education in Art Vocational Schools in Taiyuan City [J]. Taiyuan Science and Technology, 2003 (06)

[5] Liu Xiaoling. Study on the development of private colleges in the western region [J]. Guizhou Education, 2003 (09) 